\title{
The Brandt Line after forty years: The more North-South relations change, the more they stay the same?
}

\author{
Nicholas Lees* ${ }^{*}$ \\ Department of Politics, University of Liverpool, United Kingdom \\ ${ }^{\star}$ Corresponding author. Email: nicholas.lees@liverpool.ac.uk
}

(Received 30 August 2019; revised 16 September 2020; accepted 17 September 2020; first published online 16 November 2020)

\begin{abstract}
The Brandt Line is a way of visualising the world that highlights the disparities and inequalities between the wealthy North and the poorer Global South. Forty years after its popularisation as part of a call for global reform, is the Brandt Line now a misleading way of representing world politics? This article assesses whether the Global South has lost its distinctiveness and coherence relative to the North since 1980. Existing assessments of global inequality do not settle the question of whether the North-South divide remains relevant for international relations because they overlook the most politically significant measures of inequality. Drawing on power transition theory, this article provides a systematic assessment of the North-South divide in terms of levels of economic development, relative inequality, economic power, and political satisfaction. The evidence suggests that the Brandt Line is largely intact. Although the economic diversity of the South has increased and its collective economic power has risen, relative income rankings remain unaltered and the states of the Global South are as dissatisfied as they were four decades ago. Differential growth rates are reshaping world politics without eroding the North-South divide traced by the Brandt Line.
\end{abstract}

Keywords: Inequality; North-South; Brandt Line; Dissatisfaction; Power Transition

\section{Introduction}

The 'Brandt Line' is a visualisation created to illustrate international inequalities and the socioeconomic gulf that separates regions of the world, popularised in North-South: A Programme for Survival - also known as the Brandt report. Snaking across continents to divide the world into the richer North and the poorer Global South, the Brandt Line has for four decades been one of the most recognisable and influential ways of visualising world politics. Nonetheless, questions might be raised about whether the Brandt Line remains meaningful. Depicting the world as divided into an industrialised North and an underdeveloped Global South might no longer reflect the realities of world politics, if it ever did. Global economic integration, the emergence of a new international division of labour and the rise of the emerging economies might have erased the Brandt Line, or at least blurred it to the point of unrecognisability. Whatever our intuitions about these issues, the utility of the Brandt Line should be evaluated in terms of the best available evidence. The fortieth anniversary of the Brandt Report provides an opportunity to assess whether the Brandt Line is an accurate representation of the key economic and political divisions in the contemporary world. This article evaluates three prominent perspectives on the status of the North-South divide: that it was always overstated and the two categories never coherent; that the world was meaningfully divided into a North and a Global South but that a key turning point the categories ceased to have meaning; and that North-South divisions have persisted and remain relevant despite decades of change within the international system.

(C) The Author(s) 2020. Published by Cambridge University Press on behalf of the British International Studies Association. This is an Open Access article, distributed under the terms of the Creative Commons Attribution licence (http://creativecommons.org/licenses/by/4.0/), which permits unrestricted re-use, distribution, and reproduction in any medium, provided the original work is properly cited. 
There have been many theoretical and empirical analyses of the different dimensions of inequality in the present international system. Nonetheless, many of the contributions to the debate over international inequality have been made by economists, sociologists, or development studies scholars. The measures they have used focus on material welfare and interpersonal inequality, important but not necessarily the only relevant indicators for an analysis of the politics of international inequality. International Relations and political science scholars who have examined questions relating to international and global inequality have either accepted the terms of the debate established by economists and sociologists, or have focused on a narrow range of indicators mainly relating to great power status. A new systematic analysis is needed, linking indicators of material welfare and relative inequality to the political disagreements that animate some of the tensions between the North and the Global South. Utilising the most appropriate sources of data and using straightforward but relevant statistical tests, this article aims to provide a new assessment of whether and to what extent the Brandt Line remains relevant for international relations.

Although capitalist industrialisation and colonialism deepened inequalities between regions of the world, it was not until the mid-twentieth century that the international politics of inequality truly emerged. Decolonisation resulted in the entry into international society of a large number of underdeveloped and economically insecure states with recent experience of colonial domination by the European powers. Former colonies gained the status of sovereign nation-states, swelling the ranks of the 'have-nots' within international society. The result was a set of new and urgent claims about international justice. ${ }^{1}$ Early attempts to build on a shared anti-colonial stance among African and Asian states and independence movements led to the Bandung Conference in 1955. A shared sense of peripherality and dissatisfaction with the postwar global economic order led many Latin American states to move closer to the emerging Afro-Asian coalition diplomatically, resulting in the Cairo Declaration of 1962 and the creation of the United Nations Conference on Trade and Development (UNCTAD) as a platform for the development of policies to revise the rules governing the world economy. ${ }^{2}$ By 1967 the Group of 77 (G77) had emerged as the most important coalition of the states of the Global South in the UN system.

Postcolonial and late developing states began to form a bloc articulating a common set of political arguments distinct from both that of the liberal democratic capitalist West and the statesocialist East. Armed with a numerical majority in the one-member-one-vote UN General Assembly and the normative argument that the wealthier industrialised nations had a moral obligation to assist the underdeveloped world, the emerging Global South attempted to effect a transfer of economic power from the strong to the weak. The cumulation of this process was the 1973 demand for a New International Economic Order (NIEO), prompted by the oil embargo. The mirage of 'producer power' made it seem feasible that cartels of primary commodity-producing countries could act as a vanguard for the Global South and secure major concessions from the North. ${ }^{3}$ Despite attempts by the South to negotiate as a unified bloc with industrialised capitalist countries, such concessions were not forthcoming. Nonetheless, the Global South was able to influence the agenda and the debate over global economic problems. In a context of serious concern over population growth, dependence on imported resources, financial instability, and ecological limits to growth, the claims by representatives of the Global South that international inequality and poverty were both morally unacceptable and major threats to global stability were taken seriously by Northern interlocutors.

One result was North-South: A Programme for Survival, the report of a panel of experts and politicians from both the North and the South, chaired by the German Social Democrat Willy

\footnotetext{
${ }^{1}$ Hedley Bull, The Anarchical Society: A Study of Order in World Politics (3rd edn, Basingstoke: Palgrave, 2002); A. P. Rana, 'The intellectual dimensions of India's nonalignment', The Journal of Asian Studies, 28:2 (1969), pp. $299-312$.

${ }^{2}$ Robert A. Mortimer, The Third World Coalition in International Politics ( $2^{\text {nd }}$ edn, Colarado: Westview Press, 1984); Robert L. Rothstein, The Weak in the World of the Strong: Developing Countries in the International System (Guildford: Columbia University Press, 1977).

${ }^{3}$ Craig N. Murphy, The Emergence of the NIEO Ideology (Epping: Bowker Publishing Company, 1984).
} 
Brandt. ${ }^{4}$ Published in 1980, few of the proposals of North-South were ever implemented. The sense of crisis in the 1970s that had brought the North to the negotiating table had receded. The incoming Thatcher and Reagan administrations in the UK and the US were deeply unsympathetic to the call for the NIEO. The Federal Reserve's double-digit interest rate hike under Paul Volcker rendered unserviceable the debts that many states of the Global South had incurred during the previous decade of high commodity prices. Intellectual shifts at the International Monetary Fund and the World Bank resulted in a sharp shift in development orthodoxy away from statist and interventionist policies. ${ }^{5}$ The 'Lost Decade' in the 1980s experienced by many Latin American and African countries contrasted sharply with the relative success of newly industrialising Asian countries, highlighting the stark differences within the Global South in terms of economic trajectories. After the end of the Cold War, Northern states and the international financial institutions (IFIs) further promoted market-led development strategies, while states of the Global South adapted to new realities and sought market access for their exports by joining the new World Trade Organisation. In the first decade of the 2000s, the success of a set of populous emerging economies challenged the position of the states of the North, left reeling after the global financial crisis. It nonetheless underlined the divergence of fortunes among the old Global South. A new phase of great power politics and multipolarity, rather than a return to older North-South divisions, seems to beckon.

This conclusion is, at least, a widely shared interpretation. It is certainly not implausible. Nonetheless, we should not rely upon familiar narratives, nor upon an intuitive and impressionistic reading of international events. A systematic evaluation of the evidence reveals that the Brandt Line still appears to be a relevant and plausible heuristic in many respects. Focusing not just on welfare and levels of material deprivation but also North-South relative inequality and variation within the South reveals a large degree of continuity over the course of four decades. The Global South has increased its significance within the world economy, but there is no sign that states of the Global South are any less dissatisfied with their positions in global economic and political hierarchies. The hierarchy of incomes in the international system has endured, change within international income rankings largely took place within the South itself, and there is no evidence that the new emerging economies have moved away from the rest of the Global South in terms of the foreign policy positions they have staked out in multilateral institutions. The Brandt Line seems likely to offer a plausible depiction of some of the essential facts about world politics and its deep inequalities well into the twenty-first century. Indeed, given the combination of enduring political dissatisfaction and growing economic power of the Global South, such global divisions may become increasingly disruptive unless they are somehow addressed.

\section{Literature review}

\section{Inequality, power, and differential growth}

The role that international inequality plays in shaping the relations between states has long been the subject of academic interest. Scholars have debated whether the attempt by the Global South to revise the global economic order in the 1970s reflected a basic and structural incompatibility of interests among richer and poorer states. The least sympathetic perspective asserted that the states of the Global South were playing 'an old game': attempting to advance their own narrow interests through a redistribution of resources. Others argued that developing states prefer non-market forms of allocation in the world economy, as these increase their security by leaving them less

\footnotetext{
${ }^{4}$ Willy Brandt, North-South: A Programme for Survival: Report of the Independent Commission on International Development Issues (London: Pan, 1980).

${ }^{5} J a c q u e l i n e$ Best, 'Hollowing out Keynesian norms: How the search for a technical fix undermined the Bretton Woods regime', Review of International Studies, 30:3 (2004), pp. 383-404.

${ }^{6}$ Robert W. Tucker, The Inequality of Nations (New York: Basic Books, 1977), p. 156.
} 
vulnerable to fluctuations in global markets. ${ }^{7}$ More sympathetic perspectives emphasised some of the reasons that states of the Global South themselves cited as the basis of their dissatisfaction: the declining share of world trade of the Global South, the urgency of national development in poorer countries, unmet aspirations of rapid development, and the protectionist policies of the North. ${ }^{8}$

For radical perspectives such as dependency and world-systems theory, although the NIEO was a project championed by the political representatives of the dominant social classes in the developing world, it nonetheless demonstrated the existence of structural inequalities driving world politics. Economic relations between the Northern core and the Southern periphery are based on exploitation between the two macro-regions, providing the underlying antagonism that results in overt North-South political conflict in multilateral institutions. ${ }^{9}$ Despite their huge differences, these intellectual responses to the formation of the Global South as a political coalition share the view that there is an enduring, structural conflict of interests between the North and South. Intriguingly, in an important study, Keisuke Iida calculated the proportion of defections from the common voting positions of the Global South in the United Nations and found that the South's solidarity within the United Nations actually increased during the $1980 \mathrm{~s},{ }^{10}$ conventionally regarded as the nadir for South-South politics. It might be that the latent conflict between North and South is structural and enduring, even though North-South issues fluctuate into and out of prominence intermittently.

A useful integrative perspective is provided by power transition theory. ${ }^{11}$ Like hegemonic versions of realist theory, ${ }^{12}$ power transition theory holds that world orders are created by the most powerful state and allies that share its preferences. The framework of rules in world politics is created to serve the interests of the powerful and, while the existence of this institutional order might provide broader benefits, the interests of other states are not prioritised in its design or management. The result is that many states are left dissatisfied but are unlikely to be able to change the framework of rules even though they chafe within it. ${ }^{13}$ They are only likely to be able to reshape the international order if they increase their power to the point where they can either change the system by force or pressure the dominant power to accommodate them. The power transition approach perhaps underestimates the scope for other forms of peaceful change in world politics, but nonetheless provides a useful framework for thinking about some features of North-South relations. Power transition theory overlaps significantly with worldsystems theory and the leadership long cycle approach, which also posit that every international order has been built and maintained by a preeminent state acting in its own interests. ${ }^{14}$ For these approaches, inequality is a structural feature of present and past international orders, providing the peoples of the Global South with a strong set of reasons to be dissatisfied.

\footnotetext{
${ }^{7}$ Stephen D. Krasner, Structural Conflict: The Third World Against Global Capitalism (London: University of California Press).

${ }^{8}$ Craig N. Murphy, 'What the Third World wants: An interpretation of the development and meaning of the new international economic order ideology', International Studies Quarterly, 27:1 (1983), pp. 63-5.

${ }^{9}$ Samir Amin, 'Exiting the crisis of capitalism or capitalism in crisis?', Globalizations, 7:1/2 (2010), pp. 261-73; Johan Galtung, 'A structural theory of imperialism', Journal of Peace Research, 8:2 (1971), pp. 81-117.

${ }^{10}$ Keisuke Iida, 'Third World solidarity: The group of 77 in the UN General Assembly', International Organization, 42:2 (1988), pp. 375-95.

${ }^{11}$ A. F. K. Organski and Jacek Kugler, The War Ledger (Chicago: University of Chicago Press, 1980).

${ }^{12}$ Robert Gilpin, War and Change in World Politics (Cambridge: Cambridge University Press, 1981).

${ }^{13}$ Ronald L. Tammen, 'The Organski legacy: A fifty-year research program', International Interactions, 34:4 (2008), pp. 319-20.

${ }^{14}$ Christopher Chase-Dunn and Peter Grimes, 'World-systems analysis', Annual Review of Sociology, 21 (1995), pp. 387417; George Modelski and William R. Thompson, 'The long and the short of global politics in the twenty-first century: An evolutionary approach', International Studies Review, 1:2 (1999), pp. 110-40; Karen Rasler and William R. Thompson, 'Globalization and North-South inequality, 1870-2000: A factor for convergence, divergence or both?', International Journal of Comparative Sociology, 50:5-6 (2009), pp. 425-51.
} 
The states of the Global South are dissatisfied states that have repeatedly asserted that the world order is unjust and reflects the interests of the North, yet they lack the material power to effect significant change. Nonetheless, the unevenness of rates of growth could transform this deadlock. On the one hand, we might expect that states prospering within the world economy will be more satisfied with the US-led world order. ${ }^{15}$ If some states of the Global South experience growth and close the gap with the North, then the opposition of those states to the US-led order could decrease and the South could lose its coherence. On the other hand, however, as economic growth tends to translate into greater political power, economically successful states of the Global South may increase in their ability to change the system, especially if they have large populations and therefore possess a large share of total global economic output. If they remain dissatisfied as they rise, because of broader disagreement with the organisation of the world economy or a clash over non-economic values, then they may come into greater conflict with the satisfied Northern powers as they increase their capacity to challenge the existing world order. The consequences of any future transition in which the South catches up with the North, therefore, depends on which of these two tendencies is stronger.

Much of the theoretical literature points in the direction of differential growth rates as being a crucial factor in shaping North-South relations. The debate over whether the South is on course to close the economic gap is, however, riven by controversy. The orthodox Solow-Swan model asserts that growth per capita is driven by adoption of technology and investment of capital, with initial inputs of capital having a larger effect. This implies that less economically developed countries should grow faster, as they can adopt new technology and have lower stocks of capital in the form of plant and infrastructural investments. Poorer countries should benefit from 'catch-up growth' and, over time, income gaps between countries should close. This hypothesis is known as $\beta$ convergence, because it posits that the coefficient relating level of income to rate of growth should be negative. In other words, there is an inverse relationship between income and growth, producing a tendency towards income convergence in the long run. William J. Baumol presented evidence that catch-up growth has occurred, ${ }^{16}$ but this was disputed by J. Bradford DeLong, who pointed out that Baumol uses a biased sample of countries. Using a wider sample of countries, DeLong did not find evidence for convergence. ${ }^{17}$ Lant Pritchett demonstrates that major divergence between high- and low-income countries occurred between 1870 and 1960, and that from 1960 to 1990 consistent convergence only occurred in the high-income group. Convergence occurred within the North, while the societies of the Global South exhibited huge variation in rates of growth 'with some in explosive growth and others in implosive decline'. ${ }^{18}$

\section{Globalisation and international inequality}

Debates over convergence took on additional political significance during the post-Cold War push towards economic liberalisation, pioneered by Northern aid donors and the international financial institutions. Jeffery Sachs and Andrew Warner argued that the absence of convergence could be explained by the choices of individual states within the Global South, finding that lowincome countries that had embraced trade openness experienced catch-up growth. ${ }^{19}$ In the view of two influential economists associated with the World Bank, the 'globalisers' of the South had

\footnotetext{
${ }^{15}$ Susan G. Sample, 'Power, wealth and satisfaction: When do power transitions lead to conflict', Journal of Conflict Resolution, 62:9 (2018), p. 1911.

${ }^{16}$ William J. Baumol, 'Productivity growth, convergence, and welfare: What the long-run data show', The American Economic Review, 76:5 (1986), pp. 1072-85.

${ }^{17}$ J. Bradford DeLong, 'Have Productivity Levels Converged? Productivity Growth, Convergence, and Welfare in the Very Long Run', National Bureau of Economic Research Working Papers, 2419 (1987).

${ }^{18}$ Lant Pritchett, 'Divergence, big time', The Journal of Economic Perspectives, 11:3 (1997), p. 14.

${ }^{19}$ David Dollar, 'Outward-oriented developing countries really do grow more rapidly: Evidence from 95 LDCs 1976-1985', Economic Development and Cultural Change, 40:3 (1992), pp. 523-44; Jeffery Sachs and Andrew Warner, 'Economic Reform and the Process of Global Economic Integration', Brookings Papers on Economic Activity, 1 (1995).
} 
demonstrated the path out of poverty, resulting in 200 million fewer people in absolute poverty in the two decades after $1980 .^{20}$ If an open global economy does allow liberalising low-income societies to close the income gap then we would expect satisfaction with the US-led liberal order to have risen since the 1980s, perhaps with the South bifurcating into 'open' and 'closed' subgroups. Putting the issue of income convergence to one side, Charles Kenny has made the case that measures of human well-being have been converging worldwide. ${ }^{21}$ If this is the case, and the dissatisfaction of states is the result of the experience of material deprivation of large parts of their populace, then dissatisfaction of the Global South could have fallen even without income convergence.

Such optimistic arguments were challenged by Robert Hunter Wade, leading to an extended debate with Martin Wolf of the Financial Times. ${ }^{22}$ Wolf emphasised falling levels of absolute poverty, while Wade noted the enormous magnitude of existing global inequality, the very low base from which countries experiencing catch-up growth were growing from, the stagnation of middle-income countries and the role of China and India in driving almost the whole of the 'conditional convergence' trend. In subsequent contributions Wade demonstrated that the ratio of the incomes of the richest 10 per cent to the poorest 10 per cent had increased, as had Gini inequality between countries when considered as equal units rather than weighted by population. ${ }^{23}$

These arguments were broadly supported by the interpretation of the data offered by Branko Milanovic, former lead researcher in the World Bank's research department. Although the data suggest that population-weighted international inequality fell as a proportion of overall global inequality between 1980 and 2002, it did so by only 6 per cent and continued to constitute around 80 per cent of all worldwide Gini inequality. ${ }^{24}$ Furthermore, only a small number of societies actually managed to close the gap with the North - much of the fall in international inequality was not due to the South catching up with the North so much as large, poor societies catching up with middle-income societies that experienced economic stagnation or decline. ${ }^{25}$

What we can conclude from this round of the debate is that the answer to the question of whether the Global South still exists depends very much on the measure of international inequality that we use. If falling inequality is the result of poorer societies catching up to middle-income societies, as seems to have been the case in the 1990s and early 2000s, then catch-up growth may not have erased the Brandt Line and the North-South income gap. It is also worth noting that absolute income inequality between North and South has risen and will continue to rise in the medium term even if large parts of the South experience catch-up growth. ${ }^{26}$

Scholars associated with the world-systems tradition have also investigated the changing nature of the global income divide, finding that there was a trimodal international distribution of incomes throughout most of the twentieth century. ${ }^{27}$ This is consistent with the perspective that there exists a core, semi-periphery and periphery in the world economy, the latter two zones corresponding to the Global South. Subsequent research in this tradition has indicated that the world has moved to a more bimodal distribution of income, ${ }^{28}$ but this pattern may itself

\footnotetext{
${ }^{20}$ David Dollar and Aart Kraay, 'Spreading the wealth', Foreign Affairs, January/February (2002).

${ }^{21}$ Charles Kenny, 'Why are we worried about income? Nearly everything that matters is converging', World Development, 33:1 (2005), pp. 1-19.

${ }^{22}$ Robert Hunter Wade and Martin Wolf, 'Are global poverty and inequality getting worse?', in David Held and Anthony G. McGrew (eds), The Global Transformations Reader (Cambridge: Polity Press, 2003).

${ }^{23}$ Robert Hunter Wade, 'Is globalization reducing poverty and inequality?', World Development, 32:4 (2004), pp. 576-7.

${ }^{24}$ Branko Milanovic, 'Global Inequality and the Global Inequality Extraction Ratio: The Story of the Past Two Centuries', The World Bank Development Research Group Poverty and Inequality Team, Policy Research Working Paper, 5044 (2009).

${ }^{25}$ Branko Milanovic, World Apart: Measuring International and Global Inequality (Woodstock: Princeton University Press, 2005).

${ }^{26}$ William R. Thompson and Rafael Reuveny, Limits to Globalization: North-South Divergence (London: Routledge, 2009$)$, ch. 1.

${ }^{27}$ Giovanni Arrighi and Jessica Drangel, 'The stratification of the world-economy: An exploration of the semiperipheral zone', Review, 10:1 (1986), pp. 9-74.

${ }^{28}$ Salvatore J. Babones, 'The country-level income structural of the world-economy', Journal of World-Systems Research, 9:1 (2005), pp. 29-55.
} 
have been transitional as the most recent research using the same methodology indicates that as of 2008 there were four income clusters. ${ }^{29}$ Glenn Firebaugh, a critic of world-systems and dependency theory, reaches slightly different conclusions using the Theil index of inequality, which measures the relative concentration of income in a population compared to a hypothetical completely even distribution and is especially sensitive to changes among higher incomes. Firebaugh finds that there has been a gradual decline of between-country inequality as a proportion of global inequality and a smaller rise in within-country inequality. ${ }^{30}$ This indicates that the world could be headed for a double transition in which the Global South catches up with the North in terms of average income, and inequality becomes a social rather than international phenomenon. Analysis by Milanovic, however, indicates that while the middle classes of Asia have closed some of the gap with Northern middle classes, even the poorest income groups in the North are richer than those with median incomes in India and China, ${ }^{31}$ indicating that a categorical divide persists in material standards of living.

\section{International convergence, South-South divergence?}

The discussion of the relevance of these trends for international politics has been connected closely to the debate over the emerging economies. The idea that Brazil, Russia, India, and China (the original BRICs nations) occupy as a special position as large societies with a high future growth potential has been very influential both academically and politically. This is despite the fact that the four are heterogeneous in terms of their levels of development and place within the global division of labour, similar mainly in that they are all demographically and economically large. ${ }^{32}$ This focus on size indicates that many scholars and commentators preferred to evaluate the rise of the emerging powers in terms of great power politics rather than North-South relations. Nonetheless, the first decade of the twenty-first century saw a partial revival of a common Southern economic agenda in multilateral organisations. Whereas in 1995 states of the Global South scrambled to join a global trade organisation designed by the major Northern trading states, at Seattle in 2000 and then at Cancún in 2003 coalitions of Southern states were able to block US and European proposals during World Trading Organisation negotiations. ${ }^{33}$ Achieving a stalemate was considered a relative success given existing power symmetries, strengthening South-South solidarity.

The emerging economies were key to these new coalitions: Brazil and India played leadership roles and were able to provide technical research in support of a common Southern platform. ${ }^{34}$ Andrew Hurrell and Amrita Narlikar found efforts at leadership by these two states were driven by a mutual sense of dissatisfaction with elements of the liberal international order and identification with the broader South, but noted that both had been diversifying and developing their relations beyond the South as well. ${ }^{35}$ Beyond trade, the emerging powers invested diplomatic

\footnotetext{
${ }^{29}$ Şahan Savaş Karataşlı, 'The capitalist world-economy in the longue durée: Changing modes of the global diistribution of wealth, 1500-2008', Sociology of Development, 3:2 (2017), pp. 163-96.

${ }^{30}$ Glenn Firebaugh and Brian Goesling, 'Accounting for the recent decline in global income inequality', American Journal of Sociology, 110:2 (2004), pp. 283-312.

${ }^{31}$ Christopher Lakner and Branko Milanovic, 'Response to Adam Corlett's “Examining An Elephant: Globalisation and the Lower Middle Class of the Rich World"', unpublished paper (2016); Branko Milanovic, 'Global inequality of opportunity: How much of our income is determined by where we live', The Review of Economics and Statistics, 97:2 (2015), pp. 452-60.

${ }^{32}$ Leslie Elliot Armijo, 'The BRIC countries (Brazil, Russia, India, and China) as analytical category: Mirage or insight?', Asian Perspective, 31:4 (2007), pp. 7-42; Andrew F. Cooper, Agata Antkiewicz, and Timothy Shaw, 'Lessons from/for BRICSAM about South-North relations at the start of the 21 st century: Economic size trumps all else?', International Studies Review, 9 (2007), pp. 673-89.

${ }^{33}$ Amrita Narlikar and Diana Tussie, 'The G20 at the Cancun Ministerial: Developing countries and their evolving coalitions in the WTO', The World Economy, 27:7 (2004), pp. 947-66.

${ }^{34} \mathrm{Ibid}$.

${ }^{35}$ Andrew Hurrell and Amrita Narlikar, 'A new politics of confrontation? Brazil and India in multilateral trade negotiations', Global Society, 20:4 (2006), pp. 415-33.
} 
efforts in upgrading their relations with one another. India, Brazil, and South Africa formed the IBSA Dialogue Forum in 2003. The first in a series of annual BRIC summits took place in 2009, the group expanding to include South Africa in 2010. The global financial crisis and the temporary rise in prominence of the G20 grouping over the G8 also seemed to signal a shift in power and legitimacy to rising powers seeking to revise certain aspects of the global economic order, ${ }^{36}$ while climate change negotiations at Copenhagen in 2009 demonstrated the need for the North to seek the support of leading Southern states. Events in the first decade of the twenty-first century are therefore consistent with power transition theory's claim that the rise of dissatisfied states within an inflexible international order will generate political conflict.

Yet there is disagreement among observers about whether the emerging economies are driven by a continuing commitment to the Global South or their own more parochial interests and major power aspirations. The rise of China and the other emerging economies has driven demand for primary commodities and increased South-South investment and capital goods exports, restructuring the global division of labour ${ }^{37}$ and so, perhaps, existing alignments and political configurations. Some argue that India, South Africa, Brazil, and China still coordinate closely with the G77 grouping in the United Nations and do not set themselves apart from the rest of the developing world within the organisation. ${ }^{38}$ Analysis of twenty years of General Assembly speeches leads one commentator to conclude that the BRICS grouping is likely to endure as the component states share a common 'developmental-multipolar' perspective. ${ }^{39}$ Philip Nel argues that IBSA states have pressed consistently for 'inclusive multilateralism', seeking economic redistribution and greater Northern recognition for the claims of the South while also participating more actively within the existing multilateral order. ${ }^{40}$ A study of South-South development assistance practices finds that Brazil and China distinguish themselves from Northern aid donors by emphasising 'a discourse based on solidarity, horizontality, and mutual benefit with countries receiving development assistance'. ${ }^{41}$ It has been argued that these bilateral activities and the creation of rival lending institutions such as the New Development Bank (NDB) has 'transformed the landscape of development assistance', ${ }^{42}$ putting pressure on the international financial institutions. Some, however, see the IBSA states and China as having prioritised stronger relations with each other and Russia, having all but abandoned the G77 and UNCTAD. ${ }^{43}$ One of the most sophisticated recent analyses of the trajectory of Brazilian foreign policy comes to the less drastic conclusion that the country has faced a series of 'graduation dilemmas' as it searches for an international role, ${ }^{44}$ but others suggest that Brazil had already partially retreated from a South-South orientation by the end of Rousseff's presidency. ${ }^{45}$ Narlikar suggests that India has

\footnotetext{
${ }^{36}$ On the G20 and its composition, see Andrew F. Cooper, 'The G20 as an improvised crisis committee and/or a contested “steering committee" for the world', International Affairs, 86:3 (2010), pp. 741-57.

${ }^{37}$ The contribution that sets the terms for this debate is Raphael Kaplinsky and Dirk Messner, 'Introduction: The impact of Asian drivers on the developing world', World Development, 36:2 (2008), pp. 197-209.

${ }^{38}$ Silke Weinlich, 'Emerging powers at the UN: Ducking for cover?', Third World Quarterly, 35:10 (2014), p. 1835.

${ }^{39}$ Fabiano Mielniczuk, 'BRICS in the contemporary world: Changing identities, converging interests', Third World Quarterly, 34:6 (2013), p. 1088.

${ }^{40}$ Philip Nel, 'Redistribution and recognition: What emerging regional powers want', Review of International Studies, 36 (2010), pp. 951-74.

${ }^{41}$ Paulo de Renzio and Jurek Seifert, 'South-South cooperation and the future of development assistance: Mapping actors and options', Third World Quarterly, 35:10 (2014), p. 1872.

${ }^{42}$ Ali Burak Güven, 'Defending supremacy: How the IMF and World Bank navigate the challenge of rising powers', International Affairs, 93:5 (2017), p. 1154.

${ }^{43}$ John Toye, 'Assessing the G77: 50 years after UNCTAD and 40 years after the NIEO', Third World Quarterly, 35:10 (2014), p. 1772.

${ }^{44}$ Carlos R. S. Milani, Leticia Pinheiro, and Marina Regina Soares De Lima, 'Brazil's foreign policy and the "graduation dilemma”, International Affairs, 93:3 (2017), pp. 585-605.

${ }^{45}$ Danilo Marcondes and Emma Mawdsley, 'South-South in retreat? The transitions from Lula to Rousseff to Temer and Brazilian development cooperation', International Affairs, 93:3 (2017), pp. 681-99.
} 
moved towards a more constructive and integrative negotiating strategy while still positioning itself as on the side of the South, ${ }^{46}$ which creates the possibility that the South and the North could move closer together politically without the South losing its coherence.

As demonstrated by the diversity of these perspectives, qualitative research on South-South cooperation has not reached a firm consensus on the consequences of the rise of large emerging economies. Neither India nor China have openly challenged the global institutional status quo, but have rather sought to reconfigure their relationships with other major powers while continuing to express support with the wider Global South. Nonetheless, as economic growth has slowed in the IBSA and BRICS economies over the last decade, commentators have become less bullish about the prospects for a rapid redistribution of power and influence in international politics. The sense of momentum that the wider set of emerging economies seemed to possess in the previous decade has dissipated.

This reassessment finds a parallel in the renewed debate over economic convergence. Paul Johnson and Chris Papageorgiou argue that only a few developing economies in Asia have experienced genuinely transformational growth. They argue that convergence tends to occur only within clubs of historically similar countries, ${ }^{47}$ a suggestion very similar to the claim that movement between the core, semiperiphery, and periphery is rare. Their critics disagree, acknowledging that catch-up growth has been elusive historically but that since 1990 the world has witnessed 'unconditional convergence with a vengeance', especially among middle-income countries. ${ }^{48}$ Income, however, is only part of the picture, as historical inequalities have permitted some societies to build up much greater stocks of valuable assets than others. In his study of wealth across two centuries, Thomas Piketty argues that despite the very rapid accumulation of capital in Asia, the 'wealthy countries are in fact much wealthier than they sometimes think' and so the wealth disparity between North and South in terms of income-generating assets will remain in place. ${ }^{49}$

There is, therefore, little in the way of consensus about whether the Global South still exists as an economic and political reality. For the sake of comprehensibility, the various disagreements can be summarised in terms of three perspectives. The first is that 'the South' was always economically diverse, never really attained much unity, and only ever existed as a rhetorical slogan for temporary political purposes. This is consistent with the argument that the North is an economic 'convergence club' united by liberal democratic values, while the South is a residual category composed of states on very different economic trajectories that depend on the policies that they have pursued. States that pursue liberal policies are expected to join the rest of the liberal club eventually. The second perspective is that the Global South existed once but no longer. This is the tenor of a significant part of the literature on the emerging economies. Diverging economic trajectories are held to have undercut the commonalty of interests and experiences that supported Southern unity in international organisations. If the rising powers are dissatisfied, they seek revisions to the global order as individual states rather than as part of a broader coalition. Accounts differ on when the South lost its coherence and distinctiveness, with the setbacks of the early 1980s and the period of growth experienced by the emerging economies in the 2000s popular watersheds. The third perspective emphasises continuity and holds that the Global South still exists as a meaningful category in world politics. This viewpoint is expressed by scholars who note the resilience of divisions in the world economy and world politics. Either the inequalities that constitute the North-South divide still exist, despite the relative success of some Southern states, or alternatively, a Southern identity persists due to memory of similar historical experiences of exclusion and domination.

\footnotetext{
${ }^{46}$ Amrita Narlikar, 'India's role in global governance: A Modi-fication?', International Affairs, 93:1 (2017), pp. 93-111.

${ }^{47}$ Paul Johnson and Chris Papageorgiou, 'What remains of cross-country convergence?', Journal of Economic Literature, 58:1 (2020), pp. 129-75.

${ }^{48}$ Dev Patel, Justin Sandefur, and Avrind Subramanian, 'Everything You Know about Cross-Country Convergence Is (Now) Wrong' (2018).

${ }^{49}$ Thomas Piketty, Capital in the Twenty-First Century (Cambridge, MA: Harvard University Press, 2014), p. 463.
} 
In an attempt to settle some of these disagreements, a quantitative re-evaluation of the NorthSouth divide since 1980 is offered, complementing existing qualitative studies. With some qualifications, the third perspective seems is most consistent with the evidence. Catch-up in terms of real income has been slow and limited to a minority of states in the Global South, leaving income hierarchies intact. Nonetheless, in the aggregate, economic power has gradually shifted away from the North. Building on Iida's neglected analysis of South-South solidarity in the United Nations, ${ }^{50}$ the article assesses patterns of agreement and disagreement in the UN General Assembly, as the UN has for several decades been a major platform for South-South coalitionbuilding and North-South contestation over the shape of the liberal world order. The evidence is that states of the Global South remain dissatisfied with the global order and still share a common position at the UN. The centre of gravity in world politics is therefore moving towards dissatisfied states at the lower rungs of the global income hierarchy, a situation that power transition theory implies will not be stable.

\section{Methodology}

In the subsequent sections of this article, the question of whether the Global South continues to exist in international politics is examined through four quantitative investigations. These analyses compare the situation in 1980 with the most recent year for which relevant data was available.

In the analyses, membership of the Global South is defined in terms of membership of the G77. The Brandt Line is a well-known and recognisable shorthand for the North-South gap that popularises and communicates an important set of arguments about global inequality. However, to identify membership of the North and South social scientifically, we need to operationalise these categories using robust criteria. Membership of the G77 provides a valid intersubjective criterion: it requires a state to identify itself as part of the Global South and for this identity to be acknowledged and recognised. As the goal of this study is to assess whether the notion of the Global South remains meaningful forty years after the Brandt Line, we take membership of the G77 in 1980 as defining membership. Some states have left the G77 since 1980 and others have joined. By holding membership constant and following the same group of states through time, we ensure that we are not confusing changes in group membership for changes in the attributes of states. This allows us to assess whether the states that made up the South in 1980 are still a distinct and coherent group. Correspondingly, the North is operationalised as being composed of the states that were members of the Organization for Economic Cooperation and Development (OECD) in $1980 .^{51}$ States seems to regard membership of these two groupings as mutually exclusive; Mexico and South Korea left the G77 after joining the OECD. The membership lists of the two groups therefore provide a definition of the North and the Global South that states themselves find meaningful. ${ }^{52}$

Marginal cases exist. China is regarded as a member of the G77 by the other members, but despite working with the G77 it does not consider itself a member. Due to its large population, great power status, and the rapid economic growth it has experienced, China is an important state with a unique and complex relationship with the rest of the Global South. China is therefore considered both together with and separately from the rest of the Global South in the analyses that follow.

Because shared position within the world economy was a central factor in prompting the emergence of the Global South as a political grouping, three of the investigations concern the economic status of G77 states. Other factors played a role in the Global South's formation and may

\footnotetext{
${ }^{50}$ Iida, 'Third World solidarity'.

${ }^{51}$ Marc Andrew Williams, 'The Group of 77 in UNCTAD: Anatomy of a Third World Coalition' (unpublished PhD thesis, London School of Economics, 1987).

${ }^{52} \mathrm{On}$ the significance of recognition of a concept by participants in a social practice, see Nicholas Lees, 'International society is to international system as world society is to ...? Systemic and societal processes in English School theory', Journal of International Relations and Development, 19:3 (2016), pp. 285-311.
} 
continue to sustain it as a grouping, including shared experience of colonial domination and resistance to the polarising tendencies of the Cold War. However, it is difficult to measure changing interpretations of historical facts and their political influence systematically. Such aspects of international political identity in the Global South might be better studied with qualitative methods. ${ }^{53}$ The end of the Cold War reduced the importance of non-alignment in maintaining SouthSouth coalitions, but there have nonetheless been attempts by some states in the Non-Aligned Movement to unite around a common position opposed to US unilateralism and hegemony. ${ }^{54}$ Whether political shocks such as the end of the Cold War have influenced the political unity of the Global South can be assessed using data about voting agreement in the UN.

If states ostensibly of the Global South share neither a common position in the global economy, nor a distinct, shared set of political preferences about global issues, then it is not very meaningful to speak of North and South in world politics. In this scenario, nominal membership of groups such as the G77 counts for little and the notion of the Brandt Line is now redundant. We can express this sceptical argument in a series of hypotheses:

H1a: States of the Global South have moved closer to states of the North in terms of levels of economic development, operationalised in terms of income per capita.

H1b: Variance in levels of economic development has increased among states of the Global South since 1980 .

H2: The hierarchy between states of the North and the Global South in terms of income per capita has changed since 1980.

H3: In terms of total real GDP, the Global South collectively possesses a greater share of global economic power than in 1980.

H4a: The political distance between the North and the Global South, operationalised in terms of voting agreement at the United Nations, has declined since 1980.

H4b: The coherence of the Global South, operationalised in terms of voting agreement at the United Nations, is lower than that of the North and lower than it was in 1980.

The more of these hypotheses the evidence corroborates rather than falsifies, the more feasible it is to regard the notion of the Global South obsolete. Evaluating these claims may also reveal more complex patterns of change, providing further insights about continuity and change in North-South relations since 1980 .

This investigation concerns international political relations, so the analysis does not weight countries according to their population, but instead treats all sovereign states as equal and equivalent. It might be objected that treating China and India as equivalent to Cameroon and Lebanon presents a misleading picture. This would be true if this were an investigation to the economics of human well-being or a sociological analysis of the global system. But the present study is an assessment of the coherence and distinctiveness of a group of sovereign states within international society. Although it is something of a legalistic fiction to regard all states as equal, it is a fiction with important political consequences for the way in which international politics has been socially constructed. It is therefore appropriate to treat the state as the basic unit of analysis and make inter-state comparisons.

\footnotetext{
${ }^{53}$ Ayşe Zarakol, After Defeat: How the East Learned to Live with the West (Cambridge: Cambridge University Press, 2011).

${ }^{54}$ Government of India, Ministry of External Affairs, 'NAM XIII Summit, Kuala Lumpur Declaration on Continuing the Revitalisation of the Non-Aligned Movement' (2003), available at: \{https://mea.gov.in/bilateral-documents.htm?dtl/7560/ $\mathrm{NAM}+\mathrm{XIII}+$ Summit+Kuala+Lumpur+Declaration+on+Continuing+the+Revitalisation+of+the+NonAligned+Movement $\}$ accessed 1 June 2019.
} 


\section{Diversity in levels of economic development}

Is there greater variance in terms of levels of economic development within the Global South than there was in 1980? Answering this question will tell us whether the economies of the Global South have become increasingly diverse over the last four decades.

The most appropriate measure for comparing levels of economic development is Gross Domestic Product (GDP) per capita at Purchasing Power Parity (PPP). This is a measure of goods and services produced per person within an economy, with an adjustment to take account of differences in the cost of living between countries. It is not ideal as a measure of welfare, let alone human flourishing, but it nonetheless helps capture differences in real incomes and productivity between countries, a key element of the concept of economic development. The Maddison Project is the leading attempt to estimate incomes across the world for long historical time periods, building on Angus Maddison's pioneering work using historical data on economic activity and commodity prices to construct real GDP per capita estimates suitable for crosscountry comparison. ${ }^{55}$

Data indicate that per capita real incomes have increased on average for states of both the North and the South (with China included). The absolute difference between North and South grew from 12,714 to 30,903 PPP US dollars between 1980 and 2016. The G77 states grew by an average of 66 per cent over 36 years whereas the OECD states grew by 114 per cent, so when considering states as equal units, the South fell behind instead of catching up.

Figure 1 displays trends in GDP per capita at PPP US dollars for the North (OECD states) and the South (G77 states). The solid lines display the changing real incomes of the median state of the North and the Global South, that is, the states with incomes at the 50th percentile within their respective groups. The dotted lines display the interquartile range, which has increased for both, but more for the South than for the North. This is driven by the relative success of the 'upper South'. Nonetheless, by 2016 the state at the $75^{\text {th }}$ percentile in the South had only achieved the level of income of the state at the $25^{\text {th }}$ percentile for the North in 1972 . So even the state richer than three-quarters of the rest of the South in 2016 had not yet reached the income level the majority of Northern states enjoyed in 1980. It seems that even relatively successful states in the South have not crossed the original Brandt Line. Economic performance of the states in the lower quartile of real incomes in the South has been dismal.

Figure 2 displays a measure of the variation of GDP pc at PPP for both G77 and OECD states. ${ }^{56}$ It is immediately striking that the variation in terms of level of development has consistently been low among OECD societies. As others have argued, the North is a convergence club of countries in which levels of productivity and consumption are similar. The Global South has always been much more diverse. Variation in terms of level of development seems to have increased quite sharply in the early 1990s but seems to have remained relatively stable since then. It is notable that variation in GDP per capita at PPP seems to have been highest in the 1970s, during the period of Southern militancy. The Oil Crisis divided the South into producer and consumer economies, but politically the South was quite unified during this period. Yet windfalls to oil producers are perhaps different from the sort of cumulative increases in productivity that are typically associated with the concept of development. The coefficient of variation for the G77 states was also calculated with the oil-rich states of the Gulf and North Africa removed. ${ }^{57}$

\footnotetext{
${ }^{55}$ Maddison Project Database, version 2018. Jutta Bolt, Robert Inklaar, Herman de Jong, and Jan Luiten van Zanden, 'Rebasing "Maddison": New Income Comparisons and the Shape of Long-Run Economic Development', Maddison Project Working Paper, 10 (2018).

${ }^{56} \mathrm{Because}$ the real incomes have risen in most countries over the last four decades, the standard deviation of incomes will be greater even if the distribution of incomes is similar in relative terms. This will bias our evaluation and so instead we calculate the coefficient of variation for GDP pc at PPP for each group of states, which is the standard deviation of the GDP pc at PPP, divided by the mean value.

${ }^{57}$ Algeria, Bahrain, Iran, Iraq, Kuwait, Libya, Oman, Qatar, Saudi Arabia, and United Arab Emirates were dropped.
} 

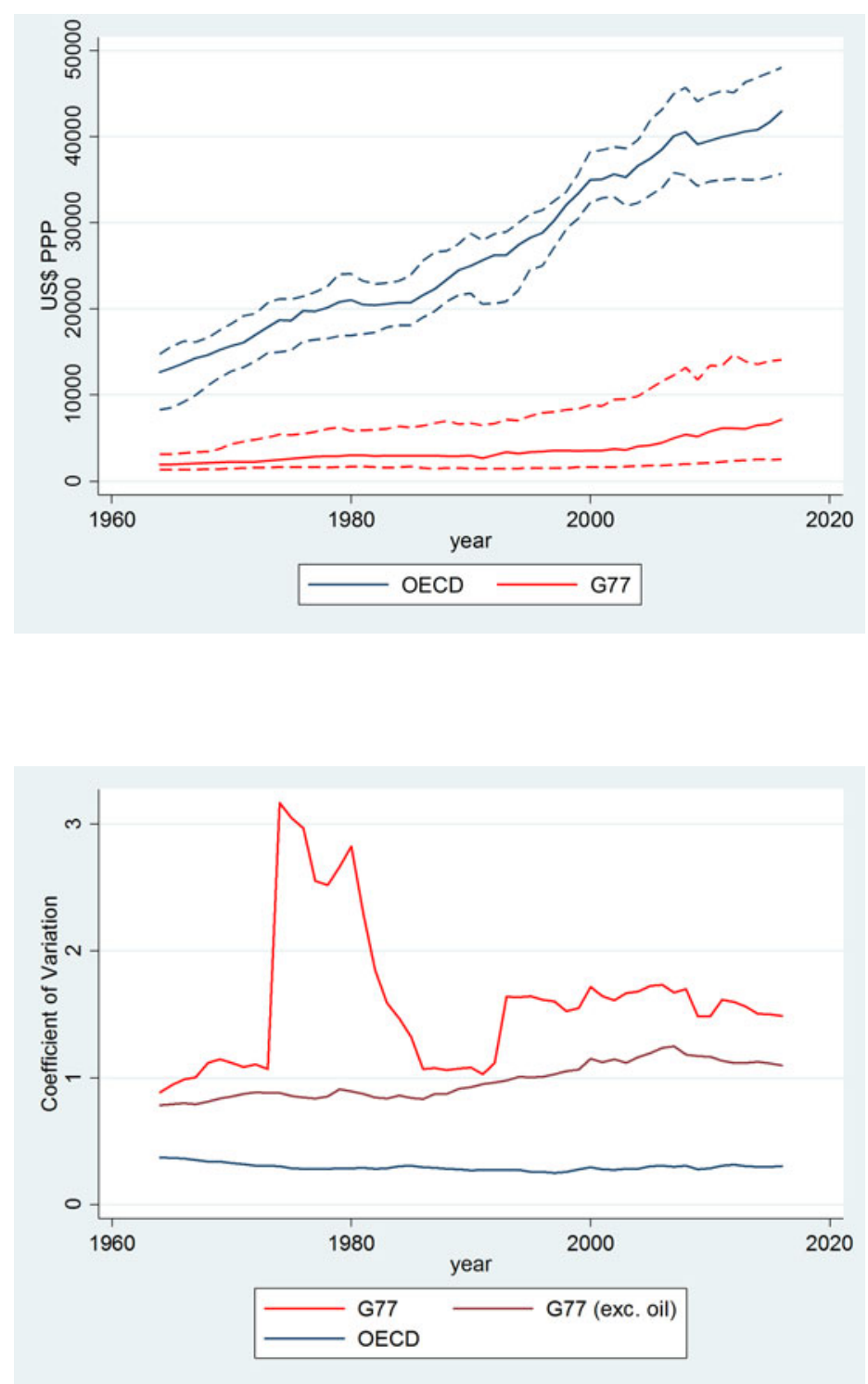

Figure 1. Real incomes in the North and Global South over time, based on Maddison Project data. Solid lines show the average real incomes of the median state of each group, dashed lines the average real incomes at the 25th and 75th percentiles.
Figure 2. The dispersion of average incomes in the North and Global South over time, based on Maddison Project data.

The changes are much less dramatic, with a gradual increase in the dispersion of levels of economic development until 2007.

The evidence indicates that, while the gap between the typical state in the Global South and the typical state in the North is larger than ever, income levels within the Global South are more dispersed than in 1980. The South has gradually become more heterogenous due to the different economic trajectories of its component states. This seems to be driven by the growing gap between the best and the worst economic performers in the Global South. Nonetheless, there is still little overlap between the North and the historical South. Excluding oil producers, very few states that were members of the G77 in 1980 have caught up with even the poorer states of the OECD. Moreover, the Global South has always been diverse in terms of incomes and levels of economic development. Commodity price fluctuations can transform the fortunes of states in the Global South, dramatically increasing the income-differences between states. Yet during the 
period of high oil prices and maximum economic diversity in the 1980s, the Global South was united and vociferous about pressing its collective claims. Therefore, there may not be a straightforward relationship between similarity of income-levels and political unity within the Global South.

\section{Stability in the global income hierarchy}

Does the hierarchy of incomes that existed in 1980 still exist? For political purposes, absolute differences in income levels between the North and states of the Global South might be less important than relative positions within a global ranking of incomes.

Using Maddison Project data on GDP per capita at PPP US dollars, we ranked all G77 and OECD countries in terms of income for 1980 and 2015. The rankings are very consistent, with a high degree of correlation and concordance between global income rankings in 1980 and $2015 .^{58}$ Perhaps this is not surprising, four decades might not be enough to overturn the global income hierarchy. Nonetheless, these tests demonstrate how little the relative positions of North and South have changed.

As Table 1 shows, small majority of states in both the North and the South were downwardly mobile. This seems to be because upwardly mobile states moved further up the rankings than downwardly mobile states fell. Southern states experienced diverse fortunes, but this did not result in a structural change in global hierarchies. There was no net upward mobility for the Global South: the median rank in terms of real income in 2015 was exactly the same as in 1980 for historic members of the G77. Correspondingly, the rank of the median OECD state did not change either, although there was a greater spread of rankings within the North. Nonetheless, most maintained their position, few fell very far and some, such as Ireland, managed to leapfrog to the top of the global rankings. The overall distribution of mobility in the South is striking in its symmetry: Southern states were just as likely to fall as rise in the global income rankings, and large changes in either direction were much less likely than small changes. The pattern is one of random churn rather than upward mobility.

Figure 3 is a scatterplot showing the relationship between income ranking in 1980 and income ranking in 2015. The relationship is strong and apparently linear. Points above the line of equality are states that improved their ranking, points below are those that fell. It is clear that few OECD countries declined in their relative position and that they dominate the top rankings alongside a handful of oil-producing states. The best performers in the South seem to have been Asian states that were previously at very low levels of economic development such as China, Laos, and Myanmar, plus regional overperformers such as Botswana. The most downwardly mobile states include Haiti, Libya, Syria, and Zimbabwe. Unsurprisingly, oil producers are volatile in terms of their position in global income rankings.

Overall, there is no evidence that global income hierarchies have been shaken up. The overall positions of the North and the South do not seem to have changed at all, as the median rank of states of each group was identical in 1980 and 2015. Relative, positional inequality seems very resilient - the North's dominance has not even been dented. If we imagine the states of the world as a deck of cards, ordered in terms of income, with states of the North and the Global South represented by cards of different suits, then it is as if the cards have been shuffled somewhat within their suits, but the overall deck has not been shuffled at all. The most significant trend has been a reordering of the rankings within the Global South, with industrialising Asian states moving to the top and unstable states moving to the very bottom. But in terms of relative income positions, the Brandt Line remains almost completely intact.

\footnotetext{
${ }^{58}$ Two standard measures of consistency among rankings were calculated. The Spearman's rho was 0.876 and the Kendall's tau-b was 0.698 , strong enough relationships that they would each be found less than 1 per cent of the time among random rankings (significant at the $\mathrm{p}<0.01$ threshold). Essentially, a state's ranking in 1980 is a good predictor of its ranking in 2015.
} 
Table 1. Mobility in international income rankings.

\begin{tabular}{lrr}
\hline & \multicolumn{2}{c}{ Number of states (\% of states) } \\
\cline { 2 - 3 } & \multicolumn{1}{c}{ OECD } & G77 \\
\hline Upwardly Mobile & $10(42 \%)$ & $47(45 \%)$ \\
Downwardly Mobile & $12(50 \%)$ & $54(51 \%)$ \\
No change & $2(8 \%)$ & $4(4 \%)$ \\
N & 24 & 105 \\
\hline
\end{tabular}

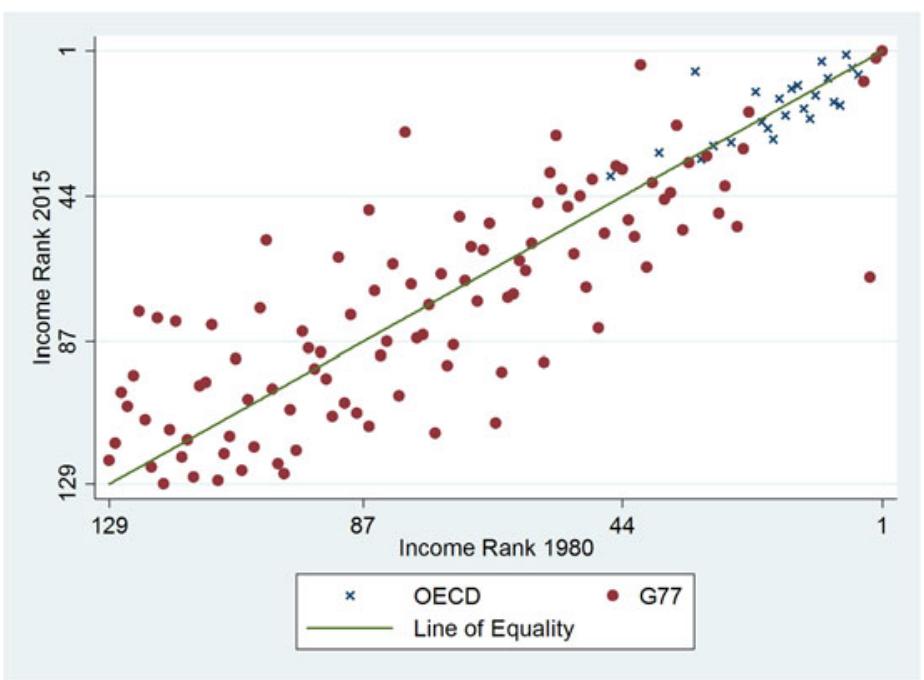

Figure 3. Income rankings in 1980 plotted against rankings in 2015, using Maddison Project data. Above the line of inequality are countries that improved their income ranking, below the line of equality are countries that fell in their income ranking.

\section{The shifting economic power of the South}

Does the South possess a greater share of economic power than it did in 1980? Purchasing Power Parity measures are often used in discussions of global inequality because they provide a way to gauge the productivity and material conditions of life in different countries. But for the purpose of assessing power transitions between groups of states, comparisons of GDP at market exchange rates (GDP FX) may be more appropriate. As Wade points out, a state's income in terms of market exchange rates is highly relevant for its ability to purchase capital goods, hire consultants and experts, represent itself in international negotiations, and repay externally denominated debt. ${ }^{59}$ Daniel Drezner argues that the key bargaining chip of states in international economic negotiations is market access: 'state power comes from the size of a government's internal market'. ${ }^{60}$ Jacob Assa, however, argues that changes to the rules for calculating GDP have led to the overestimation of the economic output of Northern societies through the inclusion of certain actual and hypothetical returns from assets. These include rents that owner-occupiers could accrue from their property, and the differential between deposits and loans. ${ }^{61}$ Carla Norloff, however, makes

\footnotetext{
${ }^{59}$ Wade, 'Is globalization reducing poverty and inequality?', p. 576.

${ }^{60}$ Daniel Drezner, All Politics is Global Explaining International Regulatory Regimes (Princeton, NJ: Princeton University Press, 2007), p. 43.

${ }^{61} \mathrm{He}$ therefore suggests subtracting the value-added of the finance, insurance and real estate sector from GDP. Jacob Assa, Gross Domestic Power: Geopolitical Economy and the History of National Accounts, Theoretical Engagements in Geopolitical Economy (Bingley: Emerald Group Publishing, 2015); Jacob Assa, The Financialization of GDP: Implications for Economic Theory and Policy (Abingdon: Routledge, 2017).
} 
Figure 4. The Global South's aggregate GDP at market exchange rates as a proportion of the North's aggregate GDP, based on World Bank data.

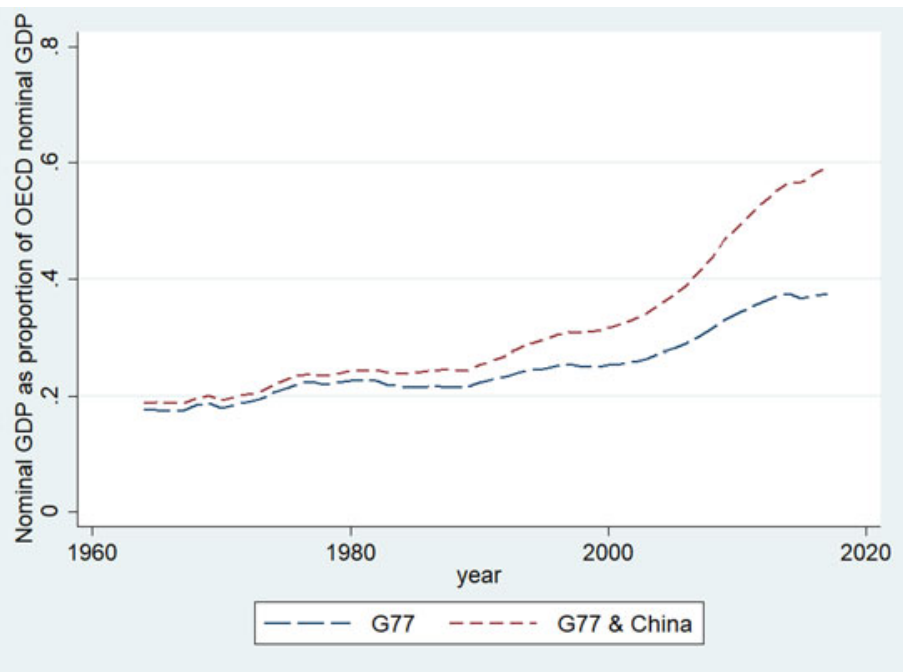

financial intermediation central to her analysis of the hegemonic role of the US in the world economy and, as Piketty notes, the assets owned by ordinary Northern households are a huge potential reserve of economic power. ${ }^{62}$ Therefore conventionally calculated nominal GDP at market exchange rates, based on World Bank data, ${ }^{63}$ might be most appropriate for assessing power shifts in the global economy.

Figure 4 shows the South's total GDP at market exchange rates as a fraction of the North's. It's clear that the South's economic output as a proportion of that of the North has nearly tripled since 1980. Much of this shift, however, is due to China. Nonetheless, even without China the South's GDP as a proportion of the North's has approximately doubled. Figure 5 shows the share of the world's GDP at market exchange rates commanded by the North, South, and China over the past few decades. The rise in China's significance in the world economy has been explosive, seemingly at the expense of the North's share of global output. In comparison, the rise of the rest of the South's share of the global product is much more modest. Nonetheless the historic OECD countries are still much larger in terms of total GDP than China and the rest of the Global South combined, notwithstanding that the latter make up the vast majority of humanity.

Using GDP at market exchange rates as a crude proxy for economic power, it does appear that there has been a power shift between North and South. China, however, has driven much but not all of this trend. Indeed, China's significance as a component of world GDP is close to that of the whole of the rest of the Global South combined. The North's dominant share of global output has been chipped away over three decades, even if income levels are very different in the North and the South. In this respect, the South is less peripheral than it was. The two sides of the Brandt Line are somewhat more equal in their economic significance than they were in 1980. If these trends continue, there will not only be a power transition between the US and China in future decades, but a broader shift in economic power between North and South.

\footnotetext{
${ }^{62}$ Carla Norrlof, America's Global Advantage: US Hegemony and International Cooperation (Cambridge: Cambridge University Press, 2010); Piketty, Capital in the Twenty-First Century.

${ }^{63}$ World Development Indicators, The World Bank, available at: \{https://databank.worldbank.org/data/reports.aspx?sour ce=world-development-indicators\# $\}$ accessed 1 March 2019.
} 


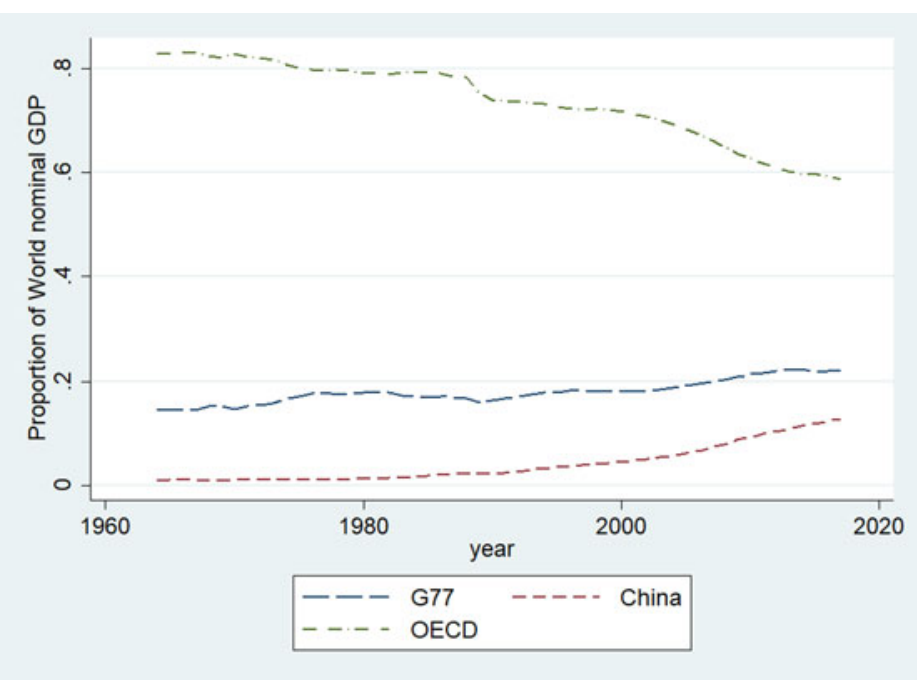

Figure 5. The North and the Global South's aggregate GDP at market exchange rates as a proportion of global aggregate GDP, based on World Bank data.

\section{Similarity of UN voting positions}

Is the Global South still a coherent group of states with similar preferences in international politics? The preceding steps in the analysis examined changing patterns of inequality and economic power within the Global South and between the North and the South. The reality appears to be more complicated and nuanced than the simple narrative of catch-up by the South and the erasure of the Brandt Line. So far we have not investigated whether changes in the political economy of inequality have had political consequences. In this section, we examine whether the historic G77 states are similarly dissatisfied with the global order. As power transition theory highlights, an increase in material power of a state that is basically content with the global order and its place in it need not lead to any significant international disruption. The rise of a group of dissatisfied states, however, is likely to lead to turbulence unless they are accommodated.

Like Iida, ${ }^{64}$ we examine South-South solidarity in terms of voting agreement in the United Nations General Assembly. Multilateral institutions and the UN have always been central to the diplomacy and coalition-building efforts of states of the Global South, from UNCTAD to the NIEO and beyond. There are various ways to assess whether two or more actors that cast votes within a political institution have similar preferences. One way is to use information on voting agreement and disagreement to construct a set of estimates of the actor's ideal points along a set of dimensions onto which policy alternatives can be mapped. In other words, we assume that political proposals can be located along one or more relevant axes such as the familiar left-right, or libertarian-authoritarian dimensions of political disagreement. When faced with a choice, actors will prefer the policy nearest to their own preferences - the option closest to their ideal point. On this basis, it is possible to infer the ideal points of political actors from their observed voting behaviour and thus generate a meaningful estimate of their political distance from one another.

Michael A. Bailey, Anton Strezhnev, and Erik Voeten ${ }^{65}$ calculate ideal points along a single dimension of disagreement for states in the UN General Assembly through an approach that separates the effect of agenda change from changing preferences. They argue that this dimension of disagreement corresponds to evaluations of the US-led liberal order. This is very useful for the present analysis, as their ideal point metric captures what we are seeking to measure: the

\footnotetext{
${ }^{64}$ Iida, 'Third World solidarity'.

${ }^{65}$ Michael A Bailey, Anton Strezhnev, and Erik Voeten, 'Estimating dynamic state preferences from United Nations voting data', Journal of Conflict Resolution, 61:2 (2017), pp. 430-56.
} 
Figure 6. The dispersion of positions taken by states of the North and the Global South in UN General Assembly votes across time, using Bailey, Strezhnev and Voeten's data.

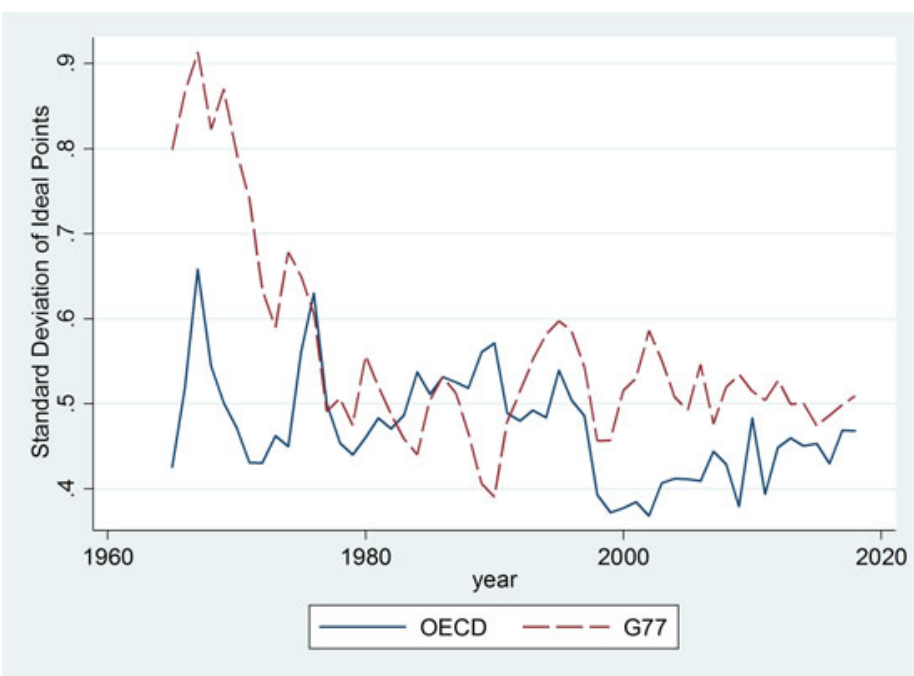

satisfaction of states with the world order established by the US and its allies. Against possible objections that the UN is a talking shop and the political positions that states take in General Assembly votes do not really reflect their foreign policies, differences in the ideal points of pairs of states has been found to be robustly associated with the chances of those states experiencing military conflict. ${ }^{66}$ If states take such differences seriously enough to use military force, we can be confident that they do reflect real and significant political disagreement.

Comparing the average ideal points of the North and the Global South in 1980 and 2018, we find that they were very different in both years. ${ }^{67}$ As expected, states of the Global South were less satisfied with the US-led liberal order than states of the North in both time periods. The difference between the political stances of the two groups of states changed little over the intervening years. Additionally, there is no evidence that the South was less coherent than the North in 1980, nor that it had become less coherent than the North by $2018 .{ }^{68}$ Despite claims to the contrary, there is no evidence whatsoever that the historic Global South has become less unified in the United Nations. There still seems to be a common South-South political platform that the majority of G77 states subscribe to.

Figure 6 displays the changes in the coherence of the North and the South, illustrating how the variation within the two groupings has changed over time. It appears that the states of the historic South started to adopt much more similar political positions shortly after the G77 was created, their coherence increasing throughout the 1970s until the early 1980s. Since then there has been little change, only year-to-year fluctuation. The North has not grown markedly more coherent or incoherent over time, although there seems to have been a period of exceptional unity in the late 1990s and early 2000s.

An alternative way of examining the changing priorities and preferences of North and South is to calculate the distance between each state's ideal point and that of the US. Figure 7 displays the

\footnotetext{
${ }^{66}$ Sample, 'Power, wealth and satisfaction'.

${ }^{67}$ Using the difference of means t-test, the differences between the mean ideal points of the North and South were significant with a $\mathrm{p}$ value of less than 0.01 .

${ }^{68}$ Levene's test provides a way of checking whether the spread of values of one set of observation is different to that of another set. We can compare the variation of the ideal points of the North and the Global South in 1980 and 2018 . A low $\mathrm{p}$ value for the test indicates a large difference that is unlikely to have arisen by chance alone, high $\mathrm{p}$ values that there is no significant difference. Comparing the North and the South in 1980, there is little difference in how much variation existed within the groupings ( $\mathrm{p}$ 0.31). The same is true for 2018 (p 0.48). Comparing the South in 1980 with the South in 2018 , we again find no significant differences in the degree of coherence ( $\mathrm{p} 0.95$ ).
} 

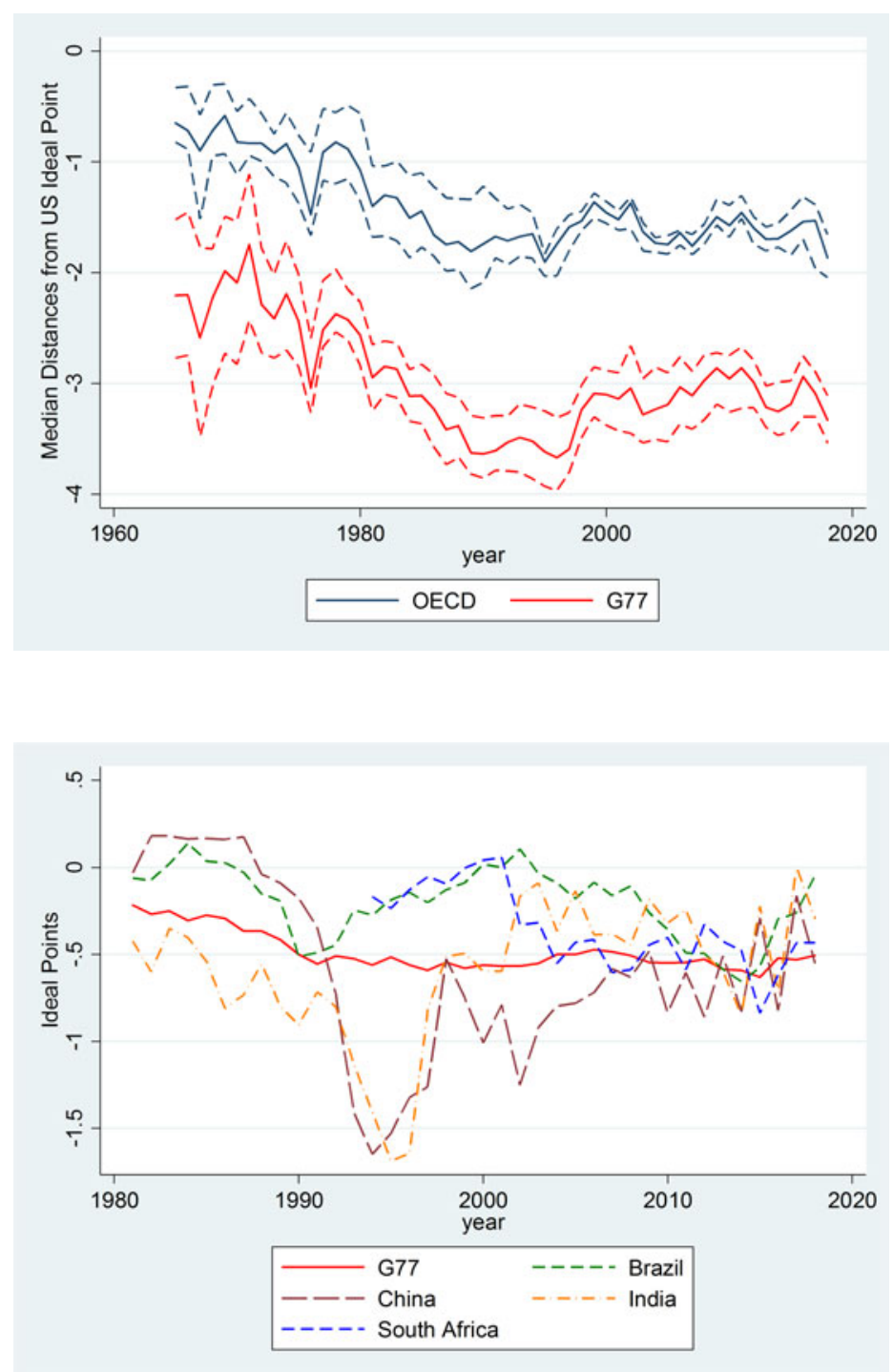

Figure 7. The median distance of states of the North and the Global South from the United States in UN General Assembly votes across time, using Bailey, Strezhnev and Voeten's data. Dashed lines show the voting positions of states at the 25th and 75th percentiles for each group.

Figure 8. The voting positions of the emerging powers and the rest of the Global South in the UN General Assembly across time, using Bailey, Strezhnev and Voeten's data.

median ideal point distances from the US for both the South and the North (excluding the US) over time. The interquartile ranges, indicated by dotted lines, never overlap. It seems clear that the South remains distinct. The 1980s and the 1990s appear to be the nadir in terms of agreement between the South and the US. The North has consistently been closer to the US than the South has been, but Northern agreement with the US appears to be falling over time. It is beyond the scope of the article to examine this, but this finding is consistent with the argument that US hegemony is gradually waning as securing the support of other advanced capitalist countries in multilateral institutions has gradually become more difficult.

Finally, Figure 8 displays trends in the political stances of the large emerging economies of the Global South. Despite the argument that the Southern BRICS are leaving the rest of the developing world behind, there is no evidence that their preferences and priorities in the UN are fundamentally different from those of the states making up the rest of the G77. China and India seem to have taken a much more oppositional stance against the liberal international order in the 1990s, perhaps reflecting their dissatisfaction with post-Cold War US unipolarity. Their position 
Table 2. Summary of findings.

\begin{tabular}{|c|c|c|c|}
\hline $\begin{array}{l}\text { Criteria for change since } \\
1980\end{array}$ & Measure & Finding & $\begin{array}{l}\text { Continuity or } \\
\text { erosion? }\end{array}$ \\
\hline $\begin{array}{l}\text { Absolute North-South } \\
\text { income difference }\end{array}$ & Comparison, GDP at PPP & The absolute income gap grew. & Continuity \\
\hline $\begin{array}{l}\text { Aggregate growth rates } \\
\text { North and South }\end{array}$ & $\begin{array}{l}\text { Comparison, \% growth, GDP at } \\
\text { PPP }\end{array}$ & $\begin{array}{l}\text { Northern states grew faster than states of } \\
\text { the Global South. }\end{array}$ & Continuity \\
\hline $\begin{array}{l}\text { Variation in incomes, } \\
\text { South }\end{array}$ & $\begin{array}{l}\text { Coefficient of variation, GDP at } \\
\text { PPP }\end{array}$ & $\begin{array}{l}\text { Variation in non-oil incomes within the } \\
\text { Global South grew. }\end{array}$ & Erosion \\
\hline $\begin{array}{l}\text { Income rankings of North } \\
\text { and South }\end{array}$ & $\begin{array}{l}\text { Comparison of, and correlation } \\
\text { between, rankings of GDP at } \\
\text { PPP }\end{array}$ & $\begin{array}{l}\text { Strong rank correlation and concordance, } \\
\text { no aggregate improvement for the } \\
\text { South. }\end{array}$ & Continuity \\
\hline $\begin{array}{l}\text { Economic power of South } \\
\text { relative to North }\end{array}$ & Relative GDP, market exchange & $\begin{array}{l}\text { The South's economic power relative to the } \\
\text { North has risen, driven largely by } \\
\text { China's growth. }\end{array}$ & Partial erosion \\
\hline $\begin{array}{l}\text { Shares of world economic } \\
\text { power, North and South }\end{array}$ & $\begin{array}{l}\text { Shares of global GDP, market } \\
\text { exchange }\end{array}$ & $\begin{array}{l}\text { The North's share of global output has } \\
\text { declined, but the South's has not risen } \\
\text { greatly exc. China. }\end{array}$ & Partial Erosion \\
\hline $\begin{array}{l}\text { Disagreement between } \\
\text { North and South }\end{array}$ & T-test, UN ideal points & No evidence of decreased disagreement. & Continuity \\
\hline $\begin{array}{l}\text { Foreign policy coherence } \\
\text { of the South }\end{array}$ & Levene's test, UN ideal points & $\begin{array}{l}\text { No evidence the South is less coherent } \\
\text { than in } 1980 .\end{array}$ & Continuity \\
\hline $\begin{array}{l}\text { Coherence of the South } \\
\text { relative to the North }\end{array}$ & Levene's test, UN ideal points & $\begin{array}{l}\text { No evidence the South is or has been less } \\
\text { coherent. }\end{array}$ & Continuity \\
\hline
\end{tabular}

seems to have softened somewhat and now approximates the G77 average. The data does provide some indication that Lula's emphasis on South-South solidarity was a temporary phase in Brazilian foreign policy: Brazil moved closer to the rest of the South during his presidency and then closer to the North under Rousseff. This corroborates the 'graduation dilemma' identified by scholars of the country's foreign policy. Nonetheless, the overall evidence is that the emerging powers are similar to the rest of the South in that they appear to be dissatisfied outsiders within the liberal international order.

\section{Conclusion}

This investigation has tested the continuing relevance of the Brandt Line in international relations using politically relevant measures of inequality and dissatisfaction. As can be seen in the summary of findings in Table 2, there is more evidence of continuity than change in the position of the Global South within the international system. Although a simplification, as all attempts to represent reality are, the Brandt Line is still a useful way to visualise important economic inequalities and political divisions in world politics. It remains meaningful to speak of the North and the Global South in international relations.

Nonetheless, the South has diversified since 1980, with members of the G77 less similar to one another in terms of level of economic development than in the past. The economic power of the Global South has grown and, while this has been driven by the rise of China, there has been a wider diffusion of the share of global output away from the North and towards the Global South. This suggests that the international system will witness not only a power transition between the US and China, but also a broader 'rise of the rest' in which economic power deconcentrates and the combined economic significance of the G77 countries approaches that of the OECD nations. International income hierarchies, however, seem strikingly stable. There has been no change to the dominance of the North at the top rungs of the global income ladder: as yet few of the most upwardly mobile non-oil economies in the Global South have caught up with the underperformers of the North. Previous research by economists and sociologists has missed this pattern through focusing on absolute, rather than comparative, national incomes 
per capita. But relative incomes are of greater political significance, as it may often be the perception of relative deprivation that sparks the demand for redistribution. ${ }^{69}$ So while improvements in incomes per capita in most of the Global South are to be welcomed, it is important not to overlook persistent income hierarchies.

Turning to measures of political similarity, the best quantitative evidence available indicates that on global issues, the Brandt Line remains relevant. States of the Global South are significantly less content than states of the North. A common Southern position in the UN General Assembly seems to exist, whether we characterise this position in terms of the struggle for power and resources, a quest for just redistribution and recognition, the desire for inclusive multilateralism, or a shared developmental multipolar perspective. While the quantitative analysis presented here cannot adjudicate decisively between these various interpretations of what the South wants, the evidence is that the South has been consistent in its demands over time. This shared position has weathered the failure of the NIEO programme, the debt crises of the 1980s, IFI-mandated structural adjustment programmes, the end of the Cold War, the era of globalisation, the War on Terror, the global financial crisis, and the rise of the BRICS. It seems risky to predict an abandonment of this common position any time soon.

Changes in absolute income levels and the rising income diversity within the South cannot explain the pattern of continuity in levels of political satisfaction. The stability of income hierarchies, however, may provide part of the explanation of why the Global South appears to be no more satisfied with the liberal international order than it was in 1980. It may be that states of the Global South act in political solidarity at the UN General Assembly because of their shared economic position vis-à-vis the North. Alternatively, the common Southern stance might be the result of a shared identity, similar preferences on issues unrelated to global political economy, or path-dependent investment in South-South diplomatic resources. Future quantitative and qualitative research might investigate these possibilities further.

Differential growth rates are gradually transforming world politics without erasing NorthSouth dividing lines. The Global South is dissatisfied and economic power is gradually slipping away from the North. Power transition theory makes a clear and unambiguous prediction: that political conflict between North and South will intensify. The absence of direct political confrontation between North and South after the failure of the NIEO programme may be better explained in terms of lack of means rather than lack of motive on the part of the South. The failure of 'producer power' and the aftermath of the debt crises meant that the states of the South could not mount an organised challenge to the liberal international order. With the rise of the emerging economies in the 2000s, a degree of combativeness returned to the Southern coalition. More modest rates of growth in the last decade have cooled optimism about South-South solidarity. Thus the degree of open political conflict between North and South in world politics has broadly followed trends in the perceived power and leverage of the South relative to the North. The underlying preferences of the Global South in aggregate do not seem to have changed very much in four decades.

Power transition theory, however, provides suggestions about how the states at the apex of the international system can avoid open conflict with rising, dissatisfied states: reduce their dissatisfaction by addressing their grievances. This would require a serious attempt by the North to engage with the South and to cede a degree of control over the architecture of the global political economy. This may prove politically challenging, but after forty years the problems identified by the Brandt Commission have not gone away - deferred but not resolved. Failing to address these issues could lead to deadlock and paralysis in multilateral institutions. The Brandt Line continues to emblematise the stark political and economic divisions of the world and, facing the shared consequences of economic turbulence and climate breakdown, a Program for Survival might be necessary to avoid global crisis.

\footnotetext{
${ }^{69}$ Ted Gurr, Why Men Rebel (Princeton, NJ: Princeton University Press, 1970).
} 
Acknowledgements. An earlier version of this article was presented at the Department of Politics Research Seminar at the University of Liverpool, organised by Dr Birte Gippert. Thanks to the reviewers and the editorial team for constructive feedback on how to improve the article.

Supplementary material. To view the online supplementary material for this article, please visit: https://doi.org/10.1017/ S026021052000039X

Nicholas Lees is a Lecturer in International Politics at the University of Liverpool. His research investigates the interrelationship between inequality, conflict, and democracy in world politics both theoretically and through quantitative methods.

Cite this article: Lees, N. 2021. The Brandt Line after forty years: The more North-South relations change, the more they stay the same? Review of International Studies 47, 85-106. https://doi.org/10.1017/S026021052000039X 